\title{
Analysis of Biofilms Formation by Cronobacter sp. during Growth in Infant Formula Milk
}

(Analisis Pembentukan Biofilem oleh Cronobacter sp. sewaktu Pertumbuhan di dalam Susu Formula Kanak-kanak)

\author{
Aishah FAiQAH Mohd Yusof, Pranesha PrabHaKARAN, Nur Diyana AZli, \\ NORRAKIAH ABDULLAH SANI \& WAN SYAIDATUL AQMA*
}

\begin{abstract}
Pacifier nipples are in permanent contact with saliva and with the oral microflora therefore, act as a favoured site for the growth of biofilms. This research was conducted to identify the bacterial biofilms that has been found on the pacifiers that collected from local child nursery and to analyse the formation of biofilms by Cronobacter sp. during growth in infant formula milk. Pacifiers collected were analysed to obtain colony forming unit (CFU) and isolated bacteria were identified using several biochemical tests according to Bergey's Manual. Biofilm assay of three Cronobacter sp. were conducted using 24 wells microtiter plate and stained with 1\% of crystal violet solution at different time interval: 6, 12, 18 and 24 $h$. The hydrophobicity of the bacterial cell suspension was evaluated using bacterial adhesion to hydrocarbons (BATH) method. Extracellular polymeric substances (EPS) analysis was done to identify percentage of carbohydrate and protein content by using phenol sulphuric acid method and Bradford method, respectively. The results obtained showed that the normal microflora bacteria were the most abundant microorganisms that were found on the pacifier with the main genus isolated was Staphylococcus $s p$., Enterobacteriaceae sp. and Clostridium sp. Based on biofilm and EPS analysis, Cronobacter sakazakii formed a strong biofilms after $18 \mathrm{~h}$, with carbohydrate was identified as main component of EPS.
\end{abstract}

Keywords: Cell surface hydrophobicity; extracellular polymeric substances (EPS); Staphylococcus sp.

\section{ABSTRAK}

Puting mempunyai sentuhan kekal dengan air liur dan mikroflora oral yang menjadikannya tapak untuk pertumbuhan biofilem. Kajian ini dijalankan untuk mengenal pasti bakteria biofilem yang terdapat pada puting yang diperoleh dari pusat jagaan kanak-kanak setempat dan untuk menganalisis pembentukan biofilem oleh Cronobacter sp. sewaktu pertumbuhan di dalam formula susu kanak-kanak. Unit penghasilan koloni telah dianalisis daripada puting dan bakteria dikenal pasti melalui kaedah biokimia berdasarkan Bergey's Manual. Asai biofilem tiga Cronobacter sp.telah dilakukan menggunakan piring microtiter 24 telaga menggunakan pewarnaan ungu hablur 1\% pada kala masa: 6, 12, 18 dan 24 jam. Hidrofobisiti permukaan sel dinilai menggunakan kaedah pelekatan bakteria pada hidrokarbon (BATH). Analisis bahan polimerik ekstrasel (EPS) dijalankan untuk mengenal pasti peratus kandungan karbohidrat dan protein menggunakan kaedah fenol asid sulfurik dan kaedah Bradford. Hasil kajian menunjukkan kebanyakan bakteria yang dipencil daripada puting adalah mikroflora normal dengan genus utama adalah daripada Staphylococcus sp. Berdasarkan analisis biofilem dan EPS menunjukkan Cronobacter sakazakii mempunyai kekuatan penghasilan biofilem pada 18 jam dengan kandungan utama adalah karbohidrat.

Kata kunci: Bahan polimerik ekstrasel (EPS); hidrofobisiti permukaan sel; Staphylococcus sp.

\section{INTRODUCTION}

The use of pacifier as a comforting device during early childhood is widespread in civilized societies but it is much debated (Mattos-Graner et al. 2000). In fact, some parents are against the use of pacifier because of the myth that state pacifiers might induce teeth disarrangements and considered pacifiers as unhygienic (Comina et al. 2006). Pacifiers permit for transudation of fluids into the middle ears, aided by pressure changes during sucking and allow for microorganisms to transfer from nasopharynx into the middle ear (Adair 2003). Still, pacifier are known to soothing infants and proven to defend against Sudden Infant Death Syndrome as it could change autonomic responses (Blood-
Siegfried 2009; Molepo \& Molaudzi 2015). It is a fact that pacifier nipples are in permanent contact with saliva and therefore with the oral microflora. For this reason, they constitute a preferential site for the growth of biofilms (Brook \& Gober 1997; Mattos-Graner et al. 2000). Oral microflora is composed of more than 100 different microbial species including pathogenic microorganisms. Saliva that contain water $(99.2 \%)$, mineral salts (sodium, potassium, chloride, calcium, carbonate and iodine), mucin and other organic materials tend to act as nutrients supplies for microorganism that present (Comina et al. 2006). Formation of biofilm also can lead to plaque formation that causes dental caries and periodontal disease in children. 
Candida sp. is the most predominant species found in used pacifiers collected from day-care centres. Candida albicans that cause oral thrush was the most common among infants up to 8 months of age. These microorganisms are proven to interfere with immune system which causes allergies, asthma and autoimmune diseases (Molepo \& Molaudzi 2015). Acute diarrhea that known as one of leading cause of child fatality in developing countries such as Nigeria are linked with infectious agents that enter via oral route (Orimadegun \& Obokon 2015). Usage of pacifier is linked to otitis media, candidiasis, intestinal parasitic infections and dental caries. Adhesion of mutans Streptococci might increase chances of dental caries in children as it is the major etiologic agents of dental caries in humans (Nelson et al.2015). Early childhood caries (ECC) are one of the most common chronic childhood diseases that affect health and well-being, thus it remain as WHO concern (Molepo \& Molaudzi 2015). Hence, disinfecting pacifiers are strongly recommended by boiling for 15 min or spraying with antimicrobial agents such as $0.12 \%$ chloehexidine (Nelson et al. 2015). Effective disinfection methods to limit pacifiers from contamination are crucial even though there are studies that prove used pacifiers can retain oral microorganism (Molepo \& Molaudzi 2015). Molepo and Molaudzi (2015) reported that alcohol- free oral rinse removed $S$. mutans from $42 \%$ of pacifiers as compared to microwave with success rate of $33 \%$. Microwaves are more effective $(83 \%)$ than alcohol-free oral rinse $(33 \%)$ in eliminating C. albicans from silicone pacifiers while microwave and alcohol-free oral rinse were equally effective in eliminating $S$. mutan from silicone pacifiers.

Biofilms can be defined as communities of microorganisms attached to a surface. Biofilm matrix are made up of $97 \%$ of water, microbial cells, secreted polymer, nutrients and metabolites, cell lysis products, particulate materials and detritus from surrounding cell (Pal \& Paul 2008). It is clear that microorganisms undergo profound changes during their transition from planktonic (freeswimming) organisms to cells that are part of complex, surface-attached community (O'toole et al. 2000). Bacterial biofilm involves cell-surface and cell-cell interaction as a part of development process (Karunakaran et al. 2011). Generally, biofilms are composed primarily of microbial cells and extracellular polymeric substances (EPS). EPS may vary in chemical and physical properties, but it is primarily composed of polysaccharides (Donlan 2002). EPS facilitate initial steps in colonization of surface (biotic and abiotic) and long-term attachment of biofilms (Nwodo $\&$ Okoh 2012). EPS create a protective layer for the cells to be resistant toward extreme environmental condition, at the same time serve as carbon source and energy reserves during starvation conditions (Singha 2012). Biosynthesis of EPS by microbial cells relies on carbon and nitrogen availability in culture medium (Czaczyk \& Myszka 2007). Studies indicate that biofilms are a stable point in a biological cycle that includes initiation, maturation, maintenance and dissolution. Bacteria initiate biofilm development in response to specific environmental signals such as nutrient availability (O'toole et al. 2000). Microorganisms on a wet surface seem able to aggregate and develop into three-dimensional structure micro colonies and thus, formed a complex layer. The formation of these sessile and resistant communities is one of the reasons towards the chronic bacterial infection (Costerton et al. 1999).

The bacterial species related to infant infection is Cronobacter sp. which causes meningitis (Dancer et al. 2009). Thus, the objectives of the present study were to identify the most abundant microorganisms on a number of used silicon pacifiers and to analyse the formation of biofilms and analysis of EPS component by Cronobacter sp. during growth in infant formula milk.

\section{MATERIALS AND METHODS}

\section{SAMPLE PREPARATION}

Fifteen used silicone and latex pacifiers were collected from a day-care centre located in Kajang, Selangor and processed within $6 \mathrm{~h}$. Briefly, one gram of cut-end pacifier was vortex with $9 \mathrm{~mL}$ saline solution. By using pour plate method, the number of colonies formed on nutrient agar after $24 \mathrm{~h}$ incubation was recorded and follow by purification to obtain single colonies. The bacterial isolates were stained for microscopic observation and identified by performing several biochemical tests according to Bergey's Manual (Holt et al. 1994). Three isolates (Cronobacter sakazaki iATCC 29544, СB2 and CB6) were obtained from culture collection in School of Chemical Sciences and Food Technology for further analysis for EPS and biofilm assay.

\section{BIOFILM ASSAY}

Bacterial adhesion and biofilms formation towards sterile polystyrene wells were analyzed by measuring the absorbance reading (OD) at different time intervals. The Cronobacter strains were inoculated into $5 \mathrm{~mL}$ tryptone soy broth (TSB) and incubated at $37^{\circ} \mathrm{C}$ for $24-48$ h. $100 \mu \mathrm{L}$ of bacterial cultures $\left(\mathrm{OD}_{660}=0.7\right)$ were transferred into 900 $\mu \mathrm{L}$ of infant formula milk into 24 wells microtiter plate and incubated at $37^{\circ} \mathrm{C}$ for four different time intervals: $6,12,18$ and $24 \mathrm{~h}$. After the incubation period, cultures were removed and the wells were rinsed thrice using sterile distilled water to remove unattached cells and dried overnight. Crystal violet aqueous solution (1\%) was added into the wells and left for 15 min followed by rinsing the wells vigorously using sterile distilled water and dried overnight. $300 \mu \mathrm{L}$ of $33 \%$ glacial acetic acid were added into the wells to detach the remaining crystal violet, absorbance reading at wavelength of $570 \mathrm{~nm}$ was taken (Dancer et al. 2009). Strains were classified as follows: $\mathrm{OD}_{570}>2=$ strong biofilm formation, $1<\mathrm{OD}_{570}$ $<2=$ moderate biofilm formation, $0.5<\mathrm{OD}_{570}<1=$ weak biofilm formation, $\mathrm{OD}_{570}<0.5=$ no biofilm formation (Mohamed et al. 2004). 


\section{ANALYSIS OF HYDROPHOBICITY}

The hydrophobicity of the bacterial cell suspension was evaluated using Bacterial adhesion to hydrocarbons (BATH) assay as described by Jain et al. (2007). In short, after 6, 12,18 and $24 \mathrm{~h}$ of incubation in 24 wells microtiter plate, the cultures were rinsed and suspended in phosphate buffer saline (0.01 M, pH7.0) and absorbance reading $\left(\mathrm{OD}_{400}\right)$ was recorded. $33.3 \mu \mathrm{L}$ of $n$-hexadecane were added into $1 \mathrm{~mL}$ bacterial cell suspension $\left(\mathrm{OD}_{540}=0.2\right)$ followed by thorough mixing and left for 15 min to allow the separation of the two phases. The absorbance reading $\left(\mathrm{OD}_{400}\right)$ of the aqueous phase was taken. The percentage of cell bound to $n$-hexadecane was calculated using equation below:

$$
\mathrm{BATH}=\left(1-\mathrm{A} / \mathrm{A}_{0}\right) \times 100,
$$

where $\mathrm{A}_{0}$ is the aqueous phase at $\mathrm{OD}_{400}$ before $n$-hexadecane was added; and $\mathrm{A}$ is the aqueous phase at $\mathrm{OD}_{400}$ after $n$-hexadecane was added.

\section{ANALYSIS OF EXTRACELLULAR POLYMERIC SUBSTANCE (EPS)}

The analysis of EPS was carried out as described by Jain and Bhosle (2008). Briefly, $1 \mathrm{~mL}$ of incubated cultures was centrifuged $(10000 \mathrm{G})$ for $15 \mathrm{~min}$ at $4^{\circ} \mathrm{C}$. Supernatants that have been obtained were used for the EPS biochemical composition analysis. The carbohydrate content of the EPS was determined by the phenol sulphuric acid method with glucose as the standard (Jaon \& Bhosele 2008). While for determination protein content, Bradford method with bovine serum albumin was used as the standard (Bradford 1976).

\section{RESULTS AND DISCUSSION}

\section{BACTERIAL ISOLATION AND IDENTIFICATION FROM PACIFIERS}

The total counts of isolated bacteria from silicone pacifiers were ranged from $2.2 \times 10^{3} \pm 5.77$ to $4.3 \times 10^{6} \pm 4.48$ $\mathrm{cfu} / \mathrm{gm}$ and from latex pacifiers were ranged from 5.2 $\times 10^{8}$ to $2.72 \times 10^{9} \mathrm{cfu} / \mathrm{gm}$. This supports that microbial population on latex nipples are more abundant than silicone nipples. Based on this study, Staphylococcus sp. is the main genus that has been isolated from silicone pacifiers, followed by Corynebacterium sp. and Bacillus $\mathrm{sp}$. This finding is supported by the study conducted by
Comina et al. (2006) that stated Staphylococcus sp. as the dominant microorganism found on pacifiers. Consequently this would increase the exposure of children towards osteomyelitis, ocular infections, endocarditis, pneumonia and even meningitis. Streptococcus mutans was reported as main cause of dental caries and one of the bacteria causing infectious endocarditis in children with congenital heart disease. Meanwhile, Enterobacteriaceae sp. and Clostridium sp. were found to be the main genus that had been isolated from latex pacifiers and Pseudomonas sp. was identified in a small amount. About $80 \%$ of microbial contamination in used silicone and latex pacifiers are mainly contaminated with Stapylococcus sp. and Candida sp. (Molepo \& Molaudzi 2015). Microbial population on latex nipples are more abundant than silicone nipples with differences of a $2.10^{4}$ - fold. This may due to the fact that the surface of silicone nipple is smoother compared to the latex nipple, thus lowering the adhesion of microbial cells (Comina et al. 2006).

\section{BIOFILMS FORMATION}

Biofilm formation by $C$. sakazakii showed that $C$. sakazakii ATCC 29544 and CB2 formed a strong biofilms after 18 $\mathrm{h}$ incubation period, whereas, CB6 showed a moderate biofilms production (Table 1). Decrement of biofilm formation was observed after $24 \mathrm{~h}$ which might due to the microorganisms had entered dissolution process. In the absence of milk, the results showed weak biofilms production by all the three strains. This showed that biofilms formation by Cronobacter sp. was induced by the nutrient contained in milk. The growth curve for Cronobacter sakazakii has been constructed for the $24 \mathrm{~h}$ time interval with $2 \mathrm{~h}$ lag period (Figure 1).

\section{CELL SURFACE HYDROPHOBICITY}

The percentages of cell surface hydrophobicity were found to increase in all three strains after $18 \mathrm{~h}$ of incubation period which were reflected with the biofilms formation strength (Table 2). The results suggested the cell surface hydrophobicity allowed a strong cell attachment to surfaces in the presence of milk as nutrient source. The formations of biofilms were proved to be related to the cell surface hydrophobicity. The increment of hydrophobicity influenced the cell attachment to the surface in order to develop a strong biofilms formation (Basson et al. 2007).

TABLE 1. Biofilms formation by Cronobacter sakazakii after 6, 12, 18 and $24 \mathrm{~h}$

\begin{tabular}{lcccc}
\hline Bacteria & \multicolumn{4}{c}{ Biofilms formation $\left(\mathrm{OD}_{570}\right)$} \\
\cline { 2 - 5 } & $6 \mathrm{~h}$ & $12 \mathrm{~h}$ & $18 \mathrm{~h}$ & $24 \mathrm{~h}$ \\
\hline C. sakazakii ATCC 29544 & $1.23 \pm 0.00^{(++)}$ & $1.96 \pm 0.01^{(++)}$ & $2.17 \pm 0.10^{(+++)}$ & $1.55 \pm 0.26^{(++)}$ \\
C. sakazakii CB2 & $1.35 \pm 0.33^{(++)}$ & $1.06 \pm 0.23^{(++)}$ & $2.50 \pm 0.22^{(++)}$ & $1.89 \pm 0.43^{(++)}$ \\
C. sakazakii CB6 & $0.48 \pm 0.20^{(-)}$ & $1.08 \pm 0.87^{(++)}$ & $1.09 \pm 0.87^{(++)}$ & $0.82 \pm 0.09^{(+)}$ \\
\hline
\end{tabular}

+++, strong; ++, moderate; +, weak; -, no biofilms formation

Data obtained was averaged based on triplicate samples 


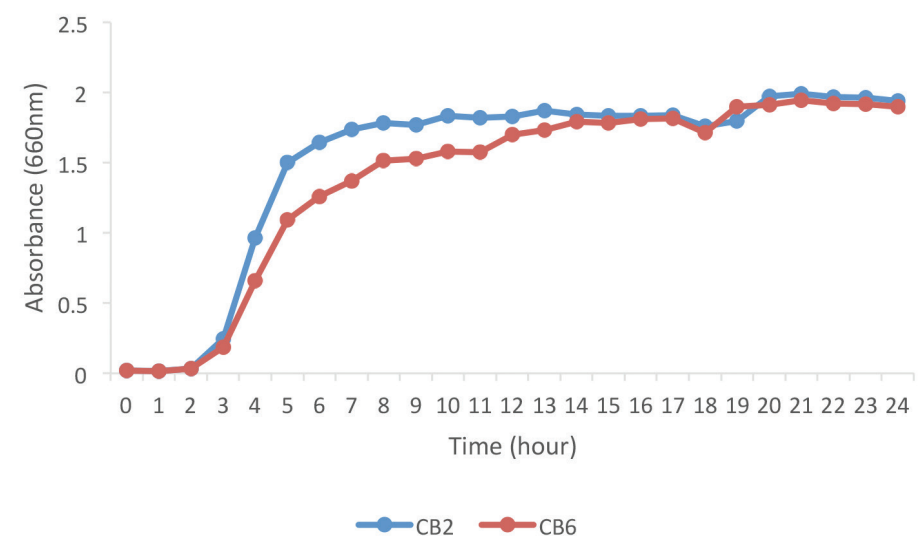

FIGURE 1. The growth curve of Cronobacter sakazakii

TABLE 2. Cell surface hydrophobicity of Cronobacter sakazakii after 6, 12, 18 and $24 \mathrm{~h}$

\begin{tabular}{lcccc}
\hline Bacteria & \multicolumn{4}{c}{$\%$ BATH } \\
\cline { 2 - 5 } & $6 \mathrm{~h}$ & $12 \mathrm{~h}$ & $18 \mathrm{~h}$ & $24 \mathrm{~h}$ \\
\hline C. sakazakii ATCC 29544 & $0 \pm 0.00$ & $50.68 \pm 0.42$ & $59.38 \pm 0.46$ & $37.93 \pm 0.42$ \\
C. sakazakii CB2 & $6.36 \pm 0.09$ & $41.34 \pm 0.25$ & $66.06 \pm 0.52$ & $41.16 \pm 0.43$ \\
C. sakazakii CB6 & $2.67 \pm 0.05$ & $17.07 \pm 0.28$ & $41.94 \pm 0.48$ & $61.66 \pm 1.27$ \\
\hline
\end{tabular}

Data obtained was averaged based on triplicate samples

(a)

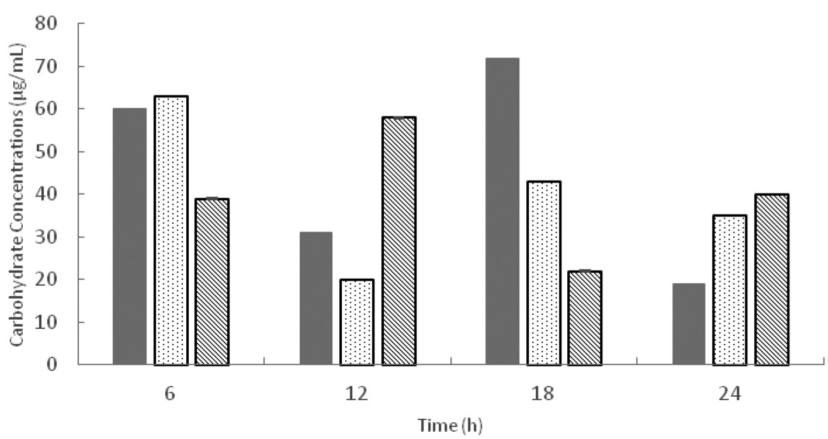

- C. sakazakii ATCC 29544 ĐC. sakazakii CB2 \$C. sakazakii CB6

(b)

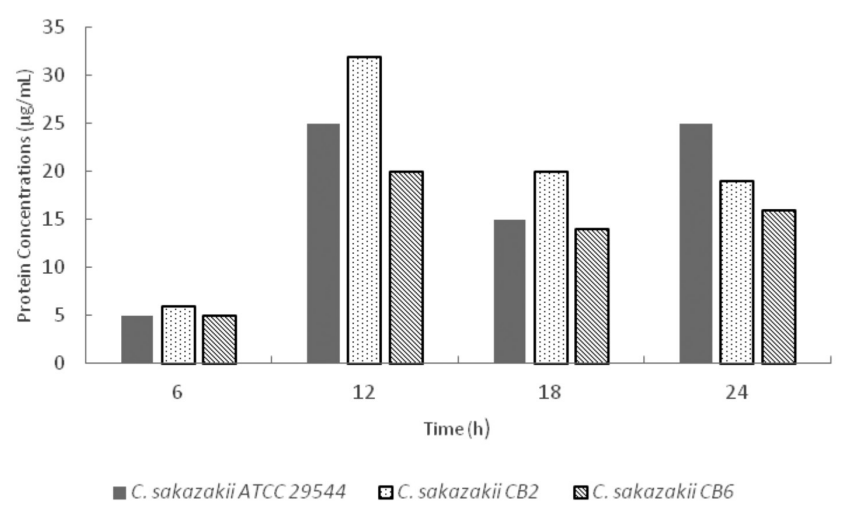

FIGURE 2. The composition of a) carbohydrate and b) protein in EPS produced by Cronobacter sakazakii after 6, 12, 18 and $24 \mathrm{~h}$ growth in infant formula milk 


\section{PRODUCTION OF EPS}

The composition of EPS indicated concentration of carbohydrates was higher than the protein (Figure 2). According to a study conducted by Bin et al. (2008), carbohydrate and protein are dominant components of EPS. The composition of EPS affects the ability of bacteria to form a biofilm. Generally, the structure of the carbohydrate has a negative charge. A strong negative charge allows better bacteria coagulation. The negative charge on extracellular polymeric material allows interaction between microorganisms and cations (Shin et al. 2000) and allows bacterial attachment as well as gaining source of nutrients.

\section{CONCLUSION}

As conclusion, bacteria found on pacifier nipple are made up of normal bacterial microflora. Cronobacter sp. capable of producing a strong adhesion after $12 \mathrm{~h}$ due to the ability to produce a hydrophobic condition with the aid of EPS production. Further studies are needed to identify factors affecting formation of biofilm in pacifiers. Proper disinfecting methods should be practiced to avoid heath complication due to microbial contamination. Findings of this study contribute to develop awareness among parents about the importance of practicing right hygienic protocol especially during handling the pacifiers.

\section{ACKNOWLEDGEMENTS}

This study was supported by the Faculty of Science and Technology, UKM and Universiti Kebangsaan Malaysia via DIP-2014-007.

\section{REFERENCES}

Adair, S.M. 2003. Pacifier use in children: A review of recent literature. Paediatric Dentistry 25(5): 449-458.

Basson, A., Flemming, L. \& Chenia, H. 2008. Evaluation of adherence, hydrophobicity, aggregation, and biofilm development of Flavobacterium johnsoniae-like isolates. Microbial Ecology 55(1): 1-14.

Bin, Z., Baosheng, S., Min, J., Taishi, G. \& Zhenghong, G. 2008. Extraction and analysis of extracellular polymeric substances in membrane fouling in submerged Mbr.Desalination 227(1): 286-294.

Blood-Siegfried, J. 2009. The role of infection and inflammation in sudden infant death syndrome. Immunopharmacology and Immunotoxicology 31(4): 516-523.

Bradford, M.M. 1976. A rapid and sensitive method for the quantitation of microgram quantities of protein utilizing the principle of protein-dye binding. Analytical Biochemistry 72(1): 248-254.

Brook, I. \& Gober, A.E. 1997. Bacterial colonization of pacifiers of infants with acute otitis media. The Journal of Laryngology \& Otology 111(07): 614-615.

Comina, E., Marion, K., Renaud, F.N., Dore, J., Bergeron, E. \& Freney, J. 2006. Pacifiers: A microbial reservoir. Nursing \& Health Sciences 8(4): 216-223.

Costerton, J.W., Stewart, P.S. \& Greenberg, E.P. 1999. Bacterial biofilms: A common cause of persistent infections. Science 284(5418): 1318-1322.
Czaczyk, K. \& Myszka, K. 2007. Biosynthesis of extracellular polymeric substances (EPS) and its role in microbial biofilm formation. Polish Journal of Environmental Studies 16(6): 799.

Dancer, G.I., Mah, J.H. \& Kang, D.H. 2009. Influences of milk components on biofilm formation of Cronobacter spp. (Enterobacter sakazakii). Letters in Applied Microbiology 48(6): 718-725.

Holt, J.G., Krieg, N.R., Sneath, P.H.A., Stanley, J.T. \& William, S.T. 1994. Bergey's Manual of Determinative Bacteriology Baltimore. Philadelphia: Lippincott Williams and Wilkins.

Jain, A. \& Bhosle, N.B. 2008. Role of B 1-4 Linked polymers in the biofilm structure of marine Pseudomonas spp. CE-2 on 304 stainless steel. Biofouling 24(4): 283-290.

Jain, A., Nishad, K.K. \& Bosle, N.B. 2007. Effects of DNP on the cell surface properties of marine bacteria and its implication for adhesion to surfaces. Biofouling 23(3-4): 171-177.

Karunakaran, E., Mukherjee, J., Ramalingam, B. \& Biggs, C.A. 2011. Applied Microbiology and Biotechnology 90: 1869-1881.

Mattos-Graner, R.O., De Moraes, A.B., Rontani, R. \& Birman, E.G. 2000. Relation of oral yeast infection in Brazilian infants and use of a pacifier. ASDC Journal of Dentistry for Children 68(1): 33-36.

Mohamed, J.A., Huang, W., Nallapareddy, S.R., Teng, F. \& Murray, B.E. 2004. Influence of origin of isolates, especially endocarditis isolates, and various genes on biofilm formation by Enterococcus faecalis. Infection and Immunity 72(6): 3658-3663.

Molepo, J. \& Molaudzi, M. 2015. Contamination and disinfection of silicone pacifiers: An in vitro study. South African Dental Journal 70(8): 351-353.

Nelson-Filho, P., Louvain, M.C., Macari, S., Lucisano, M.P., Silva, R.A.B.D., Queiroz, A.M.D., Gaton-Hernandez, P. \& Silva, L.A.B.D. 2015. Microbial contamination and disinfection methods of pacifiers. Journal of Applied Oral Science 23(5): 523-528.

Nwodo, U.U., Green, E. \& Okoh, A.I. 2012. Bacterial exopolysaccharides: Functionality and prospects.International Journal of Molecular Sciences 13(11): 14002-14015.

Orimadegun, A.E. \& Obokon, G.O. 2015. Prevalence of nonnutritive sucking habits and potential influencing factors among children in urban communities in Nigeria. Frontiers in Paediatrics 3: 30.

O’toole, G., Kaplan, H.B. \& Kolter, R. 2000 . Biofilm formation as microbial development. Annual Reviews in Microbiology 54(1): 49-79.

Pal, A. \& Paul, A.K. 2008. Microbial extracellular polymeric substances: Central elements in heavy metal bioremediation. Indian Journal of Microbiology 48(1): 49-64

Shin, H., Kang, S. \& Nam, S. 2001. Effect of carbohydrate and protein in the EPS on sludge settling characteristics. Water Science \& Technology 43(6): 193-196.

Singha, T.K. 2012. Microbial extracellular polymeric substances: Production, isolation and applications. IOSR Journal of Pharmacy 2(2): 271-281.

Aishah Faiqah Mohd Yusof, Pranesha Prabhakaran \&

Wan Syaidatul Aqma*

School of Biosciences and Biotechnology

Faculty of Science and Technology

Universiti Kebangsaan Malaysia 
43600 UKM Bangi, Selangor Darul Ehsan Malaysia

Norrakiah Abdullah Sani

School of Chemical Sciences and Food Technology

Faculty of Science and Technology

Universiti Kebangsaan Malaysia

43600 UKM Bangi, Selangor Darul Ehsan

Malaysia

Nur Diyana Azli

Department of Biotechnology

International Islamic University Malaysia (IIUM)

Bandar Indera Mahkota

25200 Kuantan, Pahang Darul Makmur

Malaysia
*Corresponding author; email: syaidatul@ukm.edu.my

Received: 19 February 2016

Accepted: 14 December 2016 